Article

\title{
Compositional and Textural Variations in Hainite-( $(Y)$ and Batievaite-(Y), Two Rinkite-Group Minerals from the Sakharjok Massif, Keivy Alkaline Province, NW Russia
}

\author{
Ekaterina A. Selivanova *, Lyudmila M. Lyalina * and Yevgeny E. Savchenko \\ Geological Institute, Kola Science Centre, Russian Academy of Sciences, 14 Fersman Str., 184209 Apatity, Russia; \\ evsav@geoksc.apatity.ru \\ * Correspondence: selivanova@geoksc.apatity.ru (E.A.S.); lialina@geoksc.apatity.ru (L.M.L.); \\ Tel.: +7-81555-7-93-33 (E.A.S.)
}

Received: 10 September 2018; Accepted: 12 October 2018; Published: 16 October 2018

\begin{abstract}
Compositional and textural variations in the rinkite group, seidozerite supergroup minerals, batievaite- $(\mathrm{Y})$, hainite- $(\mathrm{Y})$ and close to them titanosilicates from the Sakharjok massif were studied. Statistical analysis allowed for defining two major substitution schemes leading to batievaite- $(\mathrm{Y})$ and cation-deficient titanosilicates forming: $\mathrm{Ca}^{2+}+\mathrm{Na}^{+}+\mathrm{F}^{-} \leftrightarrow \square+\mathrm{Y}^{3+}+(\mathrm{OH})^{-}$and $\mathrm{Ca}^{2+}+\mathrm{Na}^{+} \leftrightarrow \square$ $+R E E^{3+}$. Batievaite- $(\mathrm{Y})$ and other cation-deficient titanosilicates are the earlier minerals formed by solid state transformation of the primary full-cation phase. Hainite- $(\mathrm{Y})$ is a later mineral. It forms rims around earlier titanosilicates, or, less often, separate crystals.
\end{abstract}

Keywords: batievaite-(Y); hainite-(Y); titanosilicate; rinkite group minerals; Kola Peninsula; Sakharjok massif; Keivy alkaline province; transformation mineral species

\section{Introduction}

Some titanosilicates, such as the rinkite group seidozerite supergroup minerals, are known to concentrate REE. Exploring the geochemical and crystal chemical behavior of $Y$ and $R E E$, we expand our notions on rare elements and their compounds for material science.

Currently, there are data on two titanosilicates of the rinkite group, the seidozerite supergroup of the Sakharjok massif, hainite-(Y) [1], and batievaite- $(\mathrm{Y})$ [2]. Batievaite- $(\mathrm{Y}) \mathrm{Y}_{2} \mathrm{Ca}_{2} \mathrm{Ti}_{[}\left[\mathrm{Si}_{2} \mathrm{O}_{7}\right]_{2}(\mathrm{OH})_{2}\left(\mathrm{H}_{2} \mathrm{O}\right)_{4}$ can be considered as a Na-deficient Y-analogue of hainite-(Y) [3].

Three-layer $\mathrm{HOH}$-blocks are common structural elements of these minerals. They have an inner O-layer formed by Ti, $\mathrm{Na}, \mathrm{Ca}, \mathrm{Mn}$, and other cations ( $\mathrm{M}^{\mathrm{O}}$ sites, Table 1$)$, with an octahedral coordination, as a rule. There are also two outer heteropolyhedral $\mathrm{H}$-layers that host 6- (7-) coordinated cations of $\mathrm{Ca}$, $R E E, \mathrm{Y}, \mathrm{Zr}\left(\mathrm{M}^{H}\right.$ sites, Table 1) linked to $\mathrm{Si}_{2} \mathrm{O}_{7}$ groups. The $\mathrm{Ti}(+\mathrm{Nb}+\mathrm{Zr}): \mathrm{Si}_{2} \mathrm{O}_{7}=1: 2$ is stoichiometric ratio for the rinkite-group minerals [4]. 
Table 1. Ideal structural formulae for rinkite group minerals.

\begin{tabular}{|c|c|c|c|c|c|c|c|}
\hline \multirow[t]{2}{*}{ Mineral } & \multicolumn{7}{|c|}{ Ideal Structural Formula } \\
\hline & $2 \mathrm{~A}^{P}$ & $2 \mathrm{M}^{H}$ & $4 \mathrm{M}^{\mathrm{O}}$ & & $\left(\mathrm{Si}_{2} \mathrm{O}_{7}\right)_{\mathrm{n}}$ & $2\left(\mathrm{X}_{\mathrm{M}}^{\mathrm{O}}\right)$ & $2\left(X^{O}\right)$ \\
\hline Mosandrite-(Ce) & $\mathrm{Ca}_{2}$ & $(\mathrm{CaREE})$ & $\left(\mathrm{H}_{2} \mathrm{O}\right)_{2} \mathrm{Ca}_{0.5 \square 0.5}$ & $\mathrm{Ti}$ & $\left(\mathrm{Si}_{2} \mathrm{O}_{7}\right)_{2}$ & $(\mathrm{OH})_{2}$ & $\left(\mathrm{H}_{2} \mathrm{O}\right)_{2}$ \\
\hline Rinkite-(Ce) & $\mathrm{Ca}_{2}$ & (CaREE) & $\mathrm{Na}(\mathrm{NaCa})$ & $\mathrm{Ti}$ & $\left(\mathrm{Si}_{2} \mathrm{O}_{7}\right)_{2}$ & $(\mathrm{OF})$ & $\mathrm{F}_{2}$ \\
\hline Rinkite-(Y) & $\mathrm{Ca}_{2}$ & $(\mathrm{CaY})$ & $\mathrm{Na}(\mathrm{NaCa})$ & $\mathrm{Ti}$ & $\left(\mathrm{Si}_{2} \mathrm{O}_{7}\right)_{2}$ & (OF) & $\mathrm{F}_{2}$ \\
\hline Nacareniobsite-(Ce) & $(\mathrm{Ca}, R E E)_{2}$ & $(\mathrm{Ca}, R E E)_{2}$ & $\mathrm{Na}_{3}$ & $\mathrm{Nb}$ & $\left(\mathrm{Si}_{2} \mathrm{O}_{7}\right)_{2}$ & (OF) & $\mathrm{F}_{2}$ \\
\hline Seidozerite & $\mathrm{Na}_{2}$ & $\mathrm{Zr}_{2}$ & $\mathrm{Na}_{2} \mathrm{Mn}$ & $\mathrm{Ti}$ & $\left(\mathrm{Si}_{2} \mathrm{O}_{7}\right)_{2}$ & $\mathrm{O}_{2}$ & $\mathrm{~F}_{2}$ \\
\hline Grenmarite & $\mathrm{Na}_{2}$ & $\mathrm{Zr}_{2}$ & $\mathrm{Na}_{2} \mathrm{Mn}$ & $\mathrm{Zr}$ & $\left(\mathrm{Si}_{2} \mathrm{O}_{7}\right)_{2}$ & $\mathrm{O}_{2}$ & $\mathrm{~F}_{2}$ \\
\hline Rosenbuschite & $\mathrm{Ca}_{4}$ & $\mathrm{Ca}_{2} \mathrm{Zr}_{2}$ & $\mathrm{Na}_{2} \mathrm{Na}_{4}$ & TiZr & $\left(\mathrm{Si}_{2} \mathrm{O}_{7}\right)_{4}$ & $\mathrm{O}_{2} \mathrm{~F}_{2}$ & $\mathrm{~F}_{4}$ \\
\hline Kochite & $\mathrm{Ca}_{2}$ & $\mathrm{MnZr}$ & $\mathrm{Na}_{3}$ & $\mathrm{Ti}$ & $\left(\mathrm{Si}_{2} \mathrm{O}_{7}\right)_{2}$ & OF & $\mathrm{F}_{2}$ \\
\hline Gotzenite & $\mathrm{Ca}_{2}$ & $\mathrm{Ca}_{2}$ & $\mathrm{NaCa}_{2}$ & $\mathrm{Ti}$ & $\left(\mathrm{Si}_{2} \mathrm{O}_{7}\right)_{2}$ & (OF) & $\mathrm{F}_{2}$ \\
\hline Hainite-(Y) & $\mathrm{Ca}_{2}$ & $(\mathrm{CaY})$ & $\mathrm{Na}(\mathrm{NaCa})$ & $\mathrm{Ti}$ & $\left(\mathrm{Si}_{2} \mathrm{O}_{7}\right)_{2}$ & (OF) & $\mathrm{F}_{2}$ \\
\hline Batievaite-(Y) & $\mathrm{Ca}_{2}$ & $\mathrm{Y}_{2}$ & $\left(\mathrm{H}_{2} \mathrm{O}\right)_{2 \square}$ & $\mathrm{Ti}$ & $\left(\mathrm{Si}_{2} \mathrm{O}_{7}\right)_{2}$ & $(\mathrm{OH})_{2}$ & $\left(\mathrm{H}_{2} \mathrm{O}\right)_{2}$ \\
\hline Fogoite- $(\mathrm{Y})$ & $\mathrm{Ca}_{2}$ & $\mathrm{Y}_{2}$ & $\mathrm{Na}_{3}$ & $\mathrm{Ti}$ & $\left(\mathrm{Si}_{2} \mathrm{O}_{7}\right)_{2}$ & $(\mathrm{OF})$ & $\mathrm{F}_{2}$ \\
\hline
\end{tabular}

* Ideal structural formulae are from [5], except for rinkite-(Y) [6].

A number of authors, who studied isomorphism in rinkite group minerals, found a linear negative correlation between $\mathrm{Na}$ and $\mathrm{Ca}$. The researchers concluded that the basic isomorphic schemes are related with cations in $\mathrm{M}^{H}-\mathrm{A}^{P}$ sites and $\mathrm{M}^{O}$ sites:

$3 \mathrm{Ca}^{2+} \leftrightarrow \mathrm{Zr}^{4+}+2 \mathrm{Na}^{+}$for the götzenite - seidozerite and götzenite - kochite series [7,8]

$2 \mathrm{Ca}^{2+} \leftrightarrow R E E^{3+}\left(\mathrm{Y}^{3+}\right)+\mathrm{Na}^{+}$for the götzenite - hainite- $(\mathrm{Y})$ series [9]

Other types of cation substitutions have also been proposed:

(1) $\mathrm{Ca}^{2+}+2 \mathrm{~F}^{-} \leftrightarrow(\mathrm{Ti}, \mathrm{Zr})^{4+}+2 \mathrm{O}^{2-}$ as main scheme for götzenite-rosenbuschite from Pian di Celli [10];

(2) $\mathrm{Ca}^{2+}+\mathrm{Ti}^{4+} \leftrightarrow \mathrm{Na}^{+}+\mathrm{Nb}^{5+}$ for the rinkite-(Ce)-nacareniobsite-(Ce) series from the Ilimaussaq complex [9];

(3) ${ }^{M}\left[\left(\mathrm{H}_{2} \mathrm{O}\right)_{2}+\square_{0.5}\right]+{ }^{X}\left[(\mathrm{OH})^{-}{ }_{2}+\left(\mathrm{H}_{2} \mathrm{O}\right)_{2}\right] \leftrightarrow{ }^{M}\left[\mathrm{Na}^{+}{ }_{2}+\mathrm{Ca}^{2+}{ }_{0.5}\right]+{ }^{X}\left[(\mathrm{OF})^{3-}+\left(\mathrm{F}_{2}\right)^{2-}\right]$ the scheme that follows from the ideal mosandrite-(Ce)-rinkite-(Ce) formula from Norway [11];

(4) $\mathrm{Ca}^{2+}+\mathrm{Na}^{+} \leftrightarrow R E E^{3+}+\square$ according to factor analysis for rinkite-(Ce)-altered rinkite-(Ce) from the Khibiny massif [12];

(5) $2\left(\mathrm{Ca}^{2+}+\mathrm{Na}^{+}\right) \leftrightarrow \mathrm{Y}^{3+}+2 \mathrm{H}_{2} \mathrm{O}+\square$ for hainite-(Y)-batievaite-(Y) from the Sakharjok massif [13].

In schemes 3-5, the correlation between $\mathrm{Na}$ and $\mathrm{Ca}$ is positive, unlike the basic pattern.

Reconstructing relations between mineral species becomes a challenge because of the opposite behavior of $\mathrm{Na}$ in hainite- $(\mathrm{Y})$ and its involvement in substitutions of the anion part (the full scheme for the hainite-(Y)-batievaite- $(\mathrm{Y})$ series: $\mathrm{Y}^{3+}+4\left(\mathrm{H}_{2} \mathrm{O}\right)+\square+2(\mathrm{OH})^{-} \leftrightarrow 2 \mathrm{Ca}^{2+}+2 \mathrm{Na}^{+}+\mathrm{O}^{2-}+3 \mathrm{~F}^{-}$, according to Table 1).

Since relations between structurally similar hainite- $(\mathrm{Y})$ and batievaite- $(\mathrm{Y})$ are still unclear, the task to analyze compositions of titanosilicates rises. Numerous individuals of those minerals co-existing show that batievaite-(Y), cation-deficient, morphologically, and chemically heterogeneous mineral, occurs in the central part of an individual. Its rims are represented by transparent well-crystallized hainite- $(\mathrm{Y})$. The calcite and analcime aggregates exist of along the boundary between batievaite- $(\mathrm{Y})$ and hainite-(Y) [14] indicates a break in the crystallization of these phases. Also, the paragenesis of analcime and calcite indicates the $\mathrm{CO}_{2}$ saturation of pegmatitic fluid due to temperature dropping down to $250-100{ }^{\circ} \mathrm{C}[14]$.

There are also individuals, where hainite-( $(Y)$ rims surround phases with an intermediate chemical composition, which is more or less close to batievaite-(Y) [14]. These compositions were not published in [1] and [2]. According to geochemical indicators- $(\mathrm{La} / \mathrm{Nd}) \mathrm{n}$ and $\mathrm{Y} / \mathrm{Dy}$ ratios, the batievaite-(Y) crystallized from $\mathrm{CO}_{2}$-rich fluid with high $\mathrm{Ca}$ activity prior to hainite-( $\left.\mathrm{Y}\right)$ that formed from relatively F-rich fluid [14].

But, the question is whether batievaite- $(\mathrm{Y})$ could be formed in the same form as we observe? It looks more like a transformational mineral species that was initially formed as a full-cation phase with the same structural elements, and then it was leached by a hydrothermal fluid, according to the 
A.P. Khomyakov principle [15]. We did not identify any sign of precursor mineral to batievaite-(Y). In this paper, we try to reconstruct the titanosilicates origin based on compositional and textural variations in the minerals.

Notably, there is the same problem with the rinkite-(Ce)-mosandrite-(Ce) series. Sokolova and Hawthorne give a cautious remark [11]: "It seems likely that mosandrite is a product of alteration of rinkite, in accord with Slepnev [16], but the rarity of mosandrite and lack of textural context do not allow elucidation of any detail of this process". Truly, though the minerals are quite common for the Khibiny and Lovozero alkaline massifs, they do not coexist. At least, such intergrowths are not thoroughly studied, but just mentioned, which is certainly not enough. It is difficult to reconstruct genetic relations for the rinkite-(Ce)-mosandrite-(Ce) series, since rinkite-(Ce) is poorly crystalline and mosandrite-(Ce) is commonly amorphous.

Some titanosilicates of the seidozerite supergroup, e.g., murmanite and lomonosovite, have similar elements $(\mathrm{HOH}$-blocks) in their structures. These minerals have cation-exchange properties $[17,18]$ and they can be easily leached. According to structural analysis, during leaching, cations remove from O-layer easier, and Na does so almost completely.

The purpose of this work is to define isomorphic schemes for rinkite group minerals from Sakharjok massif, as well as factors that are responsible for compositional variations and relations between the hainite-( $(Y)$ and batievaite- $(\mathrm{Y})$. For that, the authors statistically processed both new and published data on compositions of hainite-( $(\mathrm{Y})$ and batievaite- $(\mathrm{Y})$ from the Sakharjok, using Principal Components Analysis (PCA).

\section{Materials and Methods}

\subsection{Occurrence}

The Sakharjok is a pint-sized massif $(1.5-2 \times 8 \mathrm{~km})$ located in the central part of the Kola Peninsula, NW Russia. The main rocks are alkaline syenites, nepheline syenites, and genetically related pegmatoid schlierens and veins. The geology and petrology of the Sakharjok massif are described in details in $[19,20]$. Alkaline gabbro form minor bodies within the massif. Nepheline syenite affects the alkaline gabbro with the formation of fractures and veins that are filled by a pegmatite material. Pegmatite bodies on the contacts of such contrasting rocks have unusual mineral associations and a complex internal structure with development of aggregates of leucocratic and melanocratic minerals. Three types of mineralization are revealed: rare-earth, beryllium, and chalcophile [7,8,21]. The rinkite group minerals occur in leucocratic (major zeolitic) aggregates.

Minerals of the hainite-( $(\mathrm{Y})$-batievaite-( $\mathrm{Y})$ series occur in nepheline syenite pegmatite, Sakharjok massif as euhedral, subhedral or anhedral separate crystals and touching crystals. The size of individuals is up to $2 \mathrm{~mm}$. In hand specimens, the minerals have a milky-white, brownish, pinkish, creamy color, semi-, and non-transparent. They are colorless or transparent in thin chips. SEM analyses allow identifying heterogeneous structure and intergrowths of different mineral phases in one individual. The study shows that titanosilicates with intermediate composition or/and batievaite-(Y) compose central parts in all mineral intergrowths. Outer rims of intergrowths are formed by hainite-( $(Y)$. The contact between batievaite- $(\mathrm{Y})$ and hainite-( $(\mathrm{Y})$ is often marked by calcite and analcime aggregate. We divided the titanosilicates into six types with the following morphological features (Figures 1 and 2):

1. Hainite- $(Y)$ forms separate prismatic crystals or anhedral grains [1], but more often rims around batievaite-( $(\mathrm{Y})$ and /or titanosilicates with intermediate compositions (Figure 1a,c). Hainite-( $\mathrm{Y}$ ) refers to points 1 on PCA plots (Figure 3).

2. "Eye-like" titanosilicates are small isolated areas of rounded, ellipsoidal, or irregular shapes with clear boundaries, can have a porous structure near the boundaries "Eye-like" titanosilicates can be surrounded by hainite-(Y) (Figure 1a) or by a "layered" titanosilicate (Figure 2a,b). Within "eye", there are "heavy" phases (lighter in backscattered electron images, Figure 2a,b). "Eye-like" titanosilicates refer to points 2 on PCA plots (Figure 3). 
3. "Homogenous" titanosilicates are rounded areas ("coins") with smooth surface that occur as individuals or merge into larger areas. They occur among "loose" or "porous" titanosilicates and look like relics (Figure 2c,d). "Homogenous" titanosilicates refer to points 3 on PCA plots (Figure 3).

4. Mica-like "layered" titanosilicates are formed by numerous thin parallel layers (Figure 2f). "Layered" titanosilicates refer to points 4 on PCA plots (Figure 3).

5. "Loose" titanosilicates occur as a fractured fragile body, which is difficult to polish (Figure 1c). "Loose" titanosilicates refer to points 5 on PCA plots (Figure 3).

6. "Porous" titanosilicates are a heterogenous material with numerous point defects and cracks. The latter can be filled by a "heavy" material marked light in BSE images (Figures 1b and 2e). "Porous" titanosilicates refer to points 6 on PCA plots (Figure 3).
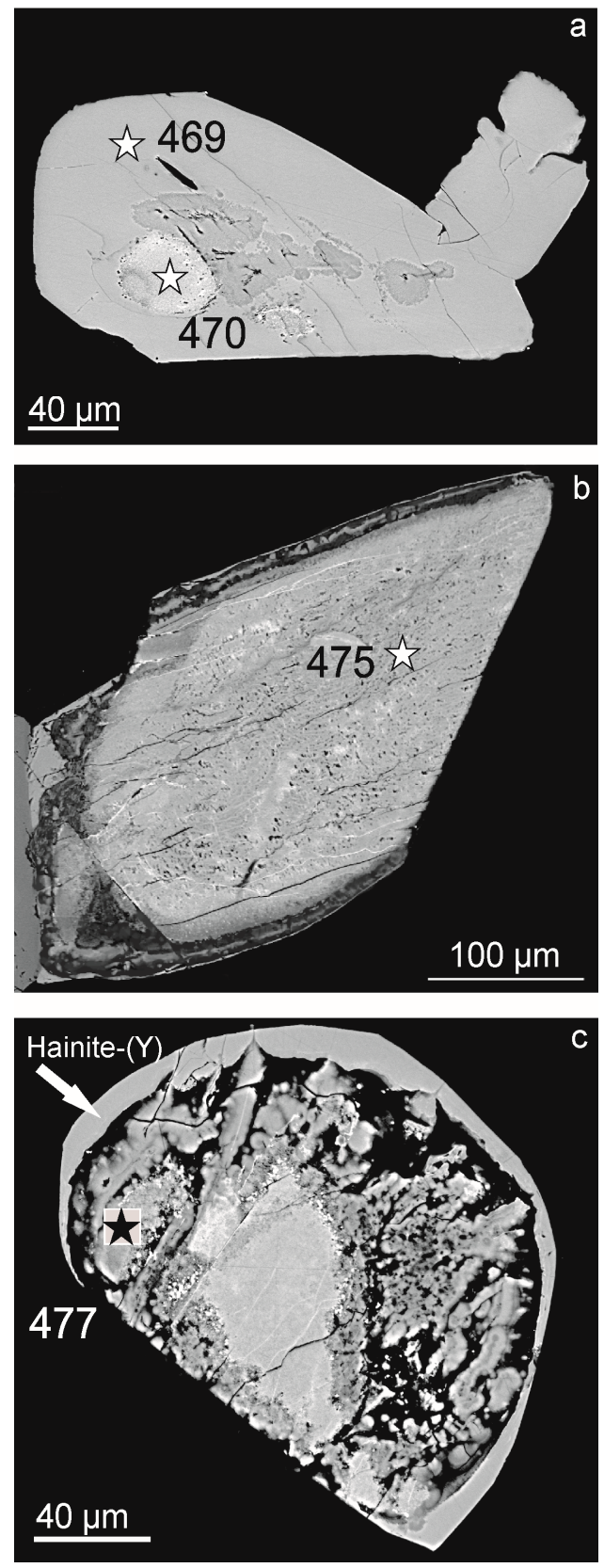

Figure 1. Morphology of titanosilicates from the nepheline syenite pegmatite, Sakharjok massif, Kola Peninsula. Backscattered electron images. Asterisks indicate point of microprobe analyses; analyses numbers correspond to Table 2. (a)_“"eye-like”titanosilicate (an. 470), hainite-(Y) (an. 469), (b)_-"porous" (an. 475), (c)_-"loose" titanosilicate (an. 477). 

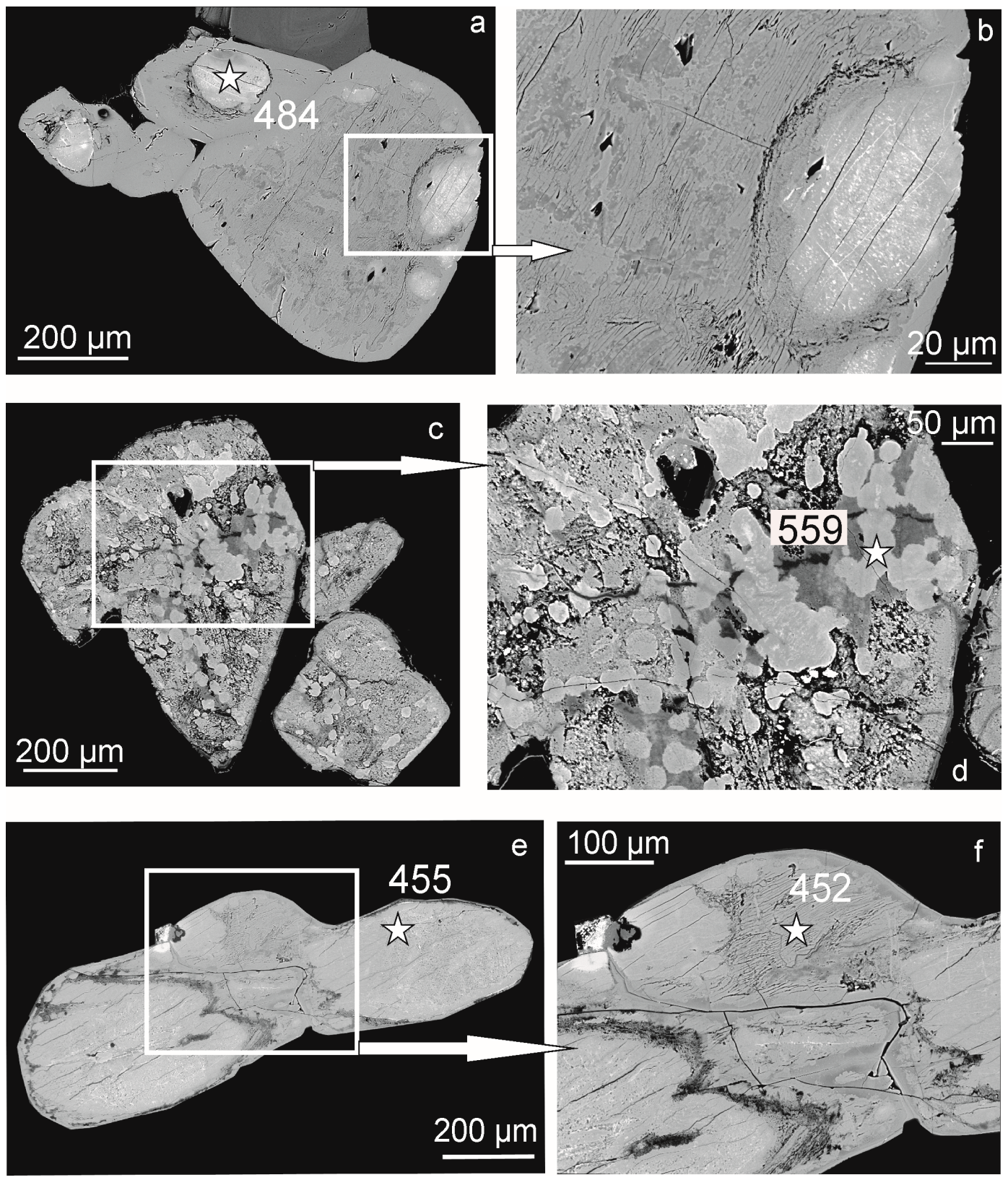

Figure 2. Morphology of titanosilicates from the nepheline syenite pegmatite, Sakharjok massif, Kola Peninsula. SEM, BSE images. Arrows to the right indicate enlarged images of the respective squared areas. Asterisks indicate point of microprobe analyses, analyses numbers correspond to Table 2 . (a,b)—“eye-like" (an. 484), (c,d)—homogenous" (an. 559), (e)—“porous" (an. 455), and (f)_-"layered" (an. 452), titanosilicates.

Table 2. Chemical compositions (wt \%) and formula coefficients (apfu) for different morphological groups of titanosilicates presented in Figures 1 and 2. Variations correspond to 79 analyses of the rinkite group minerals from the nepheline syenite pegmatite, Sakharjok massif, Kola Peninsula.

\begin{tabular}{cccccccccc}
\hline An. No. & $\mathbf{4 5 2}$ & $\mathbf{4 8 4}$ & $\mathbf{4 5 5}$ & $\mathbf{4 7 5}$ & $\mathbf{5 5 9}$ & $\mathbf{4 7 0}$ & $\mathbf{4 7 7}$ & $\mathbf{4 6 9}$ & Variation \\
\hline $\mathrm{SiO}_{2}$ & 32.39 & 32.97 & 28.63 & 29.46 & 31.62 & 30.96 & 30.54 & 30.70 & $24.60-33.03$ \\
$\mathrm{Al}_{2} \mathrm{O}_{3}$ & 1.13 & 0.91 & 2.06 & 0.90 & 0.91 & 0.73 & 1.98 & 0.43 & $0.13-2.30$ \\
$\mathrm{TiO}_{2}$ & 8.66 & 9.11 & 12.43 & 9.55 & 5.74 & 8.13 & 11.83 & 7.45 & $3.80-13.92$ \\
$\mathrm{ZrO}_{2}$ & 1.48 & 1.92 & 1.61 & 3.04 & 1.09 & 2.41 & 3.60 & 1.91 & $0.94-5.18$ \\
$\mathrm{Nb}_{2} \mathrm{O}_{5}$ & 1.63 & 1.84 & 1.60 & 2.37 & 1.02 & 2.18 & 3.03 & 1.71 & $0.35-4.78$ \\
$\mathrm{P}_{2} \mathrm{O}_{5}$ & 0.00 & 0.00 & 0.00 & 0.00 & 0.19 & 0.00 & 0.00 & 0.00 & $0-0.50$ \\
\hline
\end{tabular}


Table 2. Cont.

\begin{tabular}{|c|c|c|c|c|c|c|c|c|c|}
\hline An. No.* & 452 & 484 & 455 & 475 & 559 & 470 & 477 & 469 & Variation \\
\hline $\mathrm{MnO}$ & 0.27 & 0.33 & 2.34 & 1.72 & 1.19 & 0.58 & 0.63 & 0.15 & $0.14-8.92$ \\
\hline $\mathrm{MgO}$ & 0.11 & 0.00 & 0.27 & 0.00 & 0.45 & 0.00 & 0.00 & 0.06 & $0-0.45$ \\
\hline $\mathrm{Fe}_{2} \mathrm{O}_{3}$ & 0.19 & 0.14 & 0.28 & 0.08 & 0.22 & 0.15 & 0.21 & 0.22 & $0-0.66$ \\
\hline $\mathrm{CaO}$ & 24.64 & 24.20 & 21.86 & 22.72 & 16.29 & 26.16 & 14.67 & 27.95 & $12.28-34.73$ \\
\hline $\mathrm{Na}_{2} \mathrm{O}$ & 2.50 & 1.64 & 0.74 & 0.56 & 0.18 & 3.19 & 0.50 & 6.16 & $0.16-7.62$ \\
\hline $\mathrm{K}_{2} \mathrm{O}$ & 0.07 & 0.00 & 0.04 & 0.03 & 0.02 & 0.07 & 0.12 & 0.05 & $0-0.16$ \\
\hline $\mathrm{Y}_{2} \mathrm{O}_{3}$ & 10.87 & 11.07 & 11.23 & 12.71 & 15.35 & 10.96 & 10.41 & 9.46 & 7.61-18.51 \\
\hline $\mathrm{La}_{2} \mathrm{O}_{3}$ & 0.32 & 0.44 & 0.60 & 0.31 & 1.01 & 0.17 & 0.59 & 0.00 & $0-1.58$ \\
\hline $\mathrm{Ce}_{2} \mathrm{O}_{3}$ & 0.28 & 0.23 & 0.56 & 0.47 & 2.77 & 0.24 & 0.64 & 0.00 & $0-3.18$ \\
\hline $\mathrm{Pr}_{2} \mathrm{O}_{3}$ & 0.00 & 0.00 & 0.00 & 0.00 & 0.21 & 0.00 & 0.21 & 0.00 & $0-0.57$ \\
\hline $\mathrm{Nd}_{2} \mathrm{O}_{3}$ & 0.00 & 0.00 & 0.12 & 0.00 & 0.54 & 0.14 & 0.29 & 0.00 & $0-1.04$ \\
\hline $\mathrm{Sm}_{2} \mathrm{O}_{3}$ & 0.00 & 0.00 & 0.00 & 0.00 & 0.11 & 0.00 & 0.00 & 0.00 & $0-0.26$ \\
\hline $\mathrm{Gd}_{2} \mathrm{O}_{3}$ & 0.00 & 0.00 & 0.20 & 0.00 & 0.39 & 0.00 & 0.00 & 0.00 & $0-0.40$ \\
\hline $\mathrm{Tb}_{2} \mathrm{O}_{3}$ & 0.00 & 0.00 & 0.00 & 0.00 & 0.00 & 0.00 & 0.00 & 0.00 & $0-0.16$ \\
\hline $\mathrm{Dy}_{2} \mathrm{O}_{3}$ & 0.57 & 0.44 & 0.50 & 0.38 & 0.68 & 0.53 & 0.49 & 0.43 & $0.23-0.93$ \\
\hline $\mathrm{Ho}_{2} \mathrm{O}_{3}$ & 0.00 & 0.00 & 0.00 & 0.00 & 0.41 & 0.00 & 0.00 & 0.00 & $0-0.46$ \\
\hline $\mathrm{Er}_{2} \mathrm{O}_{3}$ & 0.71 & 0.90 & 0.94 & 0.94 & 1.27 & 1.10 & 1.37 & 0.94 & $0.71-1.61$ \\
\hline $\mathrm{Tm}_{2} \mathrm{O}_{3}$ & 0.11 & 0.36 & 0.19 & 0.34 & 0.22 & 0.24 & 0.35 & 0.25 & $0.11-0.46$ \\
\hline $\mathrm{Yb}_{2} \mathrm{O}_{3}$ & 2.38 & 2.10 & 2.00 & 2.48 & 2.14 & 2.94 & 3.35 & 2.70 & $1.83-4.02$ \\
\hline $\mathrm{Lu}_{2} \mathrm{O}_{3}$ & 0.37 & 0.52 & 0.36 & 0.61 & 0.27 & 0.44 & 0.62 & 0.39 & $0.21-0.80$ \\
\hline $\mathrm{F}$ & 3.27 & 3.46 & 1.81 & 1.85 & 0.00 & 3.31 & 1.10 & 5.95 & $0-6.80$ \\
\hline $\mathrm{Cl}$ & 0.05 & 0.00 & 0.22 & 0.15 & 0.00 & 0.10 & 0.00 & 0.00 & $0-0.35$ \\
\hline Sum & 92.00 & 92.58 & 90.57 & 90.65 & 84.27 & 94.72 & 86.50 & 96.90 & \\
\hline \multicolumn{10}{|c|}{ apfu based on $\mathrm{Si}+\mathrm{Al}=4$} \\
\hline $\mathrm{Si}$ & 3.84 & 3.87 & 3.69 & 3.86 & 3.87 & 3.89 & 3.72 & 3.94 & $3.67-3.98$ \\
\hline $\mathrm{Al}$ & 0.16 & 0.13 & 0.31 & 0.14 & 0.13 & 0.11 & 0.28 & 0.06 & $0.02-0.33$ \\
\hline $\mathrm{Ti}$ & 0.77 & 0.80 & 1.20 & 0.94 & 0.53 & 0.77 & 1.08 & 0.72 & $0.34-1.58$ \\
\hline $\mathrm{Zr}$ & 0.09 & 0.11 & 0.10 & 0.19 & 0.07 & 0.15 & 0.21 & 0.12 & $0.06-0.37$ \\
\hline $\mathrm{Nb}$ & 0.09 & 0.10 & 0.09 & 0.14 & 0.06 & 0.12 & 0.17 & 0.10 & $0.02-0.31$ \\
\hline $\mathrm{P}$ & 0.00 & 0.00 & 0.00 & 0.00 & 0.02 & 0.00 & 0.00 & 0.00 & $0-0.05$ \\
\hline $\mathrm{Mn}$ & 0.03 & 0.03 & 0.25 & 0.19 & 0.12 & 0.06 & 0.06 & 0.02 & $0.01-1.07$ \\
\hline $\mathrm{Mg}$ & 0.02 & 0.00 & 0.05 & 0.00 & 0.08 & 0.00 & 0.00 & 0.01 & $0-0.08$ \\
\hline $\mathrm{Fe}$ & 0.02 & 0.01 & 0.03 & 0.01 & 0.02 & 0.01 & 0.02 & 0.02 & $0-0.07$ \\
\hline $\mathrm{Ca}$ & 3.13 & 3.05 & 3.02 & 3.19 & 2.13 & 3.52 & 1.91 & 3.84 & $1.54-4.75$ \\
\hline $\mathrm{Na}$ & 0.57 & 0.37 & 0.18 & 0.14 & 0.04 & 0.78 & 0.12 & 1.53 & $0.04-1.86$ \\
\hline $\mathrm{K}$ & 0.01 & 0.00 & 0.01 & 0.00 & 0.00 & 0.01 & 0.02 & 0.01 & $0-0.02$ \\
\hline $\mathrm{Y}$ & 0.69 & 0.69 & 0.77 & 0.89 & 1.00 & 0.73 & 0.67 & 0.65 & $0.57-1.21$ \\
\hline $\mathrm{La}$ & 0.01 & 0.03 & 0.03 & 0.02 & 0.05 & 0.01 & 0.03 & 0.00 & $0-0.08$ \\
\hline $\mathrm{Ce}$ & 0.01 & 0.03 & 0.03 & 0.02 & 0.12 & 0.01 & 0.03 & 0.00 & $0-0.15$ \\
\hline $\operatorname{Pr}$ & 0.00 & 0.00 & 0.00 & 0.00 & 0.01 & 0.00 & 0.01 & 0.00 & $0-0.03$ \\
\hline $\mathrm{Nd}$ & 0.00 & 0.01 & 0.01 & 0.00 & 0.02 & 0.01 & 0.01 & 0.00 & $0-0.05$ \\
\hline Sm & 0.00 & 0.00 & 0.00 & 0.00 & 0.00 & 0.00 & 0.00 & 0.00 & $0-0.01$ \\
\hline $\mathrm{Gd}$ & 0.00 & 0.01 & 0.01 & 0.00 & 0.02 & 0.00 & 0.00 & 0.00 & $0-0.02$ \\
\hline $\mathrm{Tb}$ & 0.00 & 0.00 & 0.00 & 0.00 & 0.00 & 0.00 & 0.00 & 0.00 & $0-0.01$ \\
\hline Dy & 0.02 & 0.02 & 0.02 & 0.02 & 0.03 & 0.02 & 0.02 & 0.02 & $0.01-0.04$ \\
\hline Ho & 0.00 & 0.00 & 0.00 & 0.00 & 0.02 & 0.00 & 0.00 & 0.00 & $0-0.02$ \\
\hline Er & 0.03 & 0.04 & 0.04 & 0.04 & 0.05 & 0.04 & 0.05 & 0.04 & $0.03-0.07$ \\
\hline $\mathrm{Tm}$ & 0.00 & 0.01 & 0.01 & 0.01 & 0.01 & 0.01 & 0.01 & 0.01 & $0.00-0.02$ \\
\hline $\mathrm{Yb}$ & 0.09 & 0.08 & 0.08 & 0.10 & 0.08 & 0.11 & 0.12 & 0.11 & $0.07-0.19$ \\
\hline $\mathrm{Lu}$ & 0.01 & 0.01 & 0.01 & 0.02 & 0.01 & 0.02 & 0.02 & 0.02 & $0.01-0.03$ \\
\hline Sum cations & 9.59 & 9.40 & 9.94 & 9.92 & 8.49 & 10.38 & 8.56 & 11.22 & \\
\hline $\mathrm{F}$ & 1.23 & 1.29 & 0.74 & 0.77 & 0.00 & 1.32 & 0.42 & 2.41 & $0-2.73$ \\
\hline $\mathrm{Cl}$ & 0.01 & 0.00 & 0.05 & 0.03 & 0.00 & 0.02 & 0.00 & 0.00 & $0-0.08$ \\
\hline
\end{tabular}

Note. $\mathrm{Fe}_{\text {total }}$ as $\mathrm{Fe}_{2} \mathrm{O}_{3} .{ }^{*}$ No. an. Refers to Figures 1 and 2: 452, 484-"layered", 455, 475-"porous", 559-“homogenous", 470_-"eye-like", 477-“loose" titanosilicates, 469-hainite-(Y). 


\subsection{Chemical Composition}

Data on 79 analyses of rinkite group minerals were studied. Chemical analyses were carried out by means of a Cameca MS-46 electron microprobe (WDS mode, $22 \mathrm{kV}, 20-30 \mathrm{nA}, 5-20 \mu \mathrm{m}$ beam diameter, Cameca, Paris, France). The following standards (and analytical lines) were used: wollastonite $(\mathrm{SiK} \alpha, \mathrm{CaK} \alpha), \mathrm{Y}_{3} \mathrm{Al}_{5} \mathrm{O}_{12}(\mathrm{Al} K \alpha, \mathrm{Y} L \alpha)$, lorenzenite $(\mathrm{Ti} K \alpha, \mathrm{NaK} \alpha), \mathrm{ZrSiO}_{4}(\mathrm{ZrL} \alpha), \mathrm{Nb}(\mathrm{Nb} K \alpha), \mathrm{MnCO}_{3}$ $(\mathrm{MnK} \alpha)$, forsterite $(\mathrm{MgK} \alpha)$, hematite $(\mathrm{FeK} \alpha)$, wadeite $(\mathrm{KK} \alpha), \mathrm{LaCeS}_{2}(\mathrm{LaL} \alpha), \mathrm{CeS}(\mathrm{CeL} \alpha), \operatorname{LiNd}\left(\mathrm{MoO}_{4}\right)_{2}$ $(\mathrm{Nd} L \alpha), \mathrm{GdS}(\mathrm{Gd} L \alpha), \mathrm{Dy}_{3} \mathrm{Al}_{5} \mathrm{O}_{12}(\mathrm{Dy} L \alpha), \mathrm{ErPO}_{4}(\mathrm{Er} L \alpha), \mathrm{Tm}_{3} \mathrm{Al}_{5} \mathrm{O}_{12}(\operatorname{Tm} L \alpha), \mathrm{Yb}_{3} \mathrm{Al}_{5} \mathrm{O}_{12}(\mathrm{Yb} L \alpha)$, $\mathrm{Y}_{2.8} \mathrm{Lu}_{0.2} \mathrm{Al}_{5} \mathrm{O}_{12}(\mathrm{LuL} \alpha)$, atacamite $(\mathrm{ClK} \alpha)$, and fluorapatite $(\mathrm{PK} \alpha)$. The fluorine content was determined using a SEM LEO-1450 (Carl Zeiss AG, Oberkochen, Germany) equipped with an EDS XFlash-5010 Bruker Nano GmbH (Bruker Nano GmbH, Berlin, Germany). The electron microscope was operated at an acceleration voltage of $20 \mathrm{kV}$, and beam current of $0.5 \mathrm{nA}$, for an accumulation time of $200 \mathrm{~s}$. Standard-free analysis with the P/B-ZAF method of the QuanTax system was used to analyze F.

Table 2 provides chemical composition of the different textural types of titanosilicates shown on the Figures 1 and 2, variations of components and their formula coefficients (apfu) calculated based on $\mathrm{Si}+\mathrm{Al}=4$. These analyzes should not be considered representative, although they have been selected in accordance with Figures 1 and 2. They do not fully characterize the texture type, the full pool of analyses for the type is given in Supplementary Materials Table S1. Published data on batievaite-(Y) [2] correspond to some layered and porous varieties.

According to Table 2, the hainite-(Y) has the highest oxide and cations sums in comparison with other textural types of titanosilicates. Also there are significant differences in the component contents for mineral phases with a structure similar to batievaite-(Y). Numerous components and their significant and multidirectional content variations do not allow to find correlation between the texture group and the chemical composition using the "standard methods", in other words, these correlations are latent. Therefore, the PCA was chosen to detect any correlations.

\subsection{PCA}

To identify the most significant factors, and, as a consequence, the factor structure, it is most (entirely) justified to use the principal components analysis (PCA). PCA was applied using the STATISTICA 12.0 program for data processing. Formula coefficients were taken as variables. The procedure of orthogonal rotation "varimax" was applied, the Kaiser's rule became the criterion for estimating the number of principal components (factors). Supplementary Materials Table S1 provides the full set of 79 samples used for PCA.

\section{Results}

Seventy-nine mineral samples of the hainite-(Y)-batievaite-(Y) series were divided into six material types, according to their morphology. Factor Analysis (PCA) of coefficients in their formulae provided the following results. According to the Kaiser criterion, any factor that displays dispersion with an eigenvalue less than $1.00(\lambda j<1.0)$ is viewed as trivial and is not retained. These four factors satisfy this criterion (Table 3).

Table 3. Principal Components Analysis (PCA) results of the mineral composition.

\begin{tabular}{ccccc}
\hline \multirow{2}{*}{ Variable } & \multicolumn{4}{c}{ Factor Loadings } \\
\cline { 2 - 5 } & Factor 1 & Factor 2 & Factor 3 & Factor 4 \\
\hline$R E E$ & 0.756320 & 0.476891 & 0.041060 & -0.082863 \\
$\mathrm{Y}$ & 0.754054 & -0.058515 & 0.394748 & 0.054088 \\
$\mathrm{Na}$ & -0.624196 & -0.337260 & -0.420135 & -0.412386 \\
$\mathrm{~K}$ & 0.029323 & 0.141516 & 0.164027 & 0.802367 \\
$\mathrm{Mg}$ & 0.822040 & -0.288034 & 0.016398 & 0.091280 \\
$\mathrm{Ca}$ & -0.734975 & -0.183786 & 0.079822 & -0.440946 \\
$\mathrm{Ti}$ & 0.038583 & 0.595748 & 0.154522 & 0.348134 \\
\hline
\end{tabular}


Table 3. Cont.

\begin{tabular}{ccccc}
\hline \multirow{2}{*}{ Variable } & \multicolumn{4}{c}{ Factor Loadings } \\
\cline { 2 - 5 } & Factor 1 & Factor 2 & Factor 3 & Factor 4 \\
\hline $\mathrm{Zr}$ & 0.007376 & 0.643992 & 0.115776 & 0.387322 \\
$\mathrm{P}$ & 0.709521 & -0.378585 & -0.111755 & -0.071313 \\
$\mathrm{Nb}$ & -0.074589 & 0.843153 & 0.008262 & -0.076845 \\
$\mathrm{Mn}$ & 0.145517 & 0.123806 & 0.734688 & 0.044299 \\
$\mathrm{Fe}$ & -0.150331 & -0.055727 & 0.037116 & -0.700456 \\
$\mathrm{~F}$ & -0.715492 & -0.339113 & -0.316716 & -0.439336 \\
$\mathrm{Cl}$ & -0.012788 & 0.038252 & 0.883334 & 0.069680 \\
Expl.Var & 3.813428 & 2.240130 & 1.839141 & 1.999090 \\
Prp.Totl & 0.272388 & 0.160009 & 0.131367 & 0.142792 \\
\hline
\end{tabular}

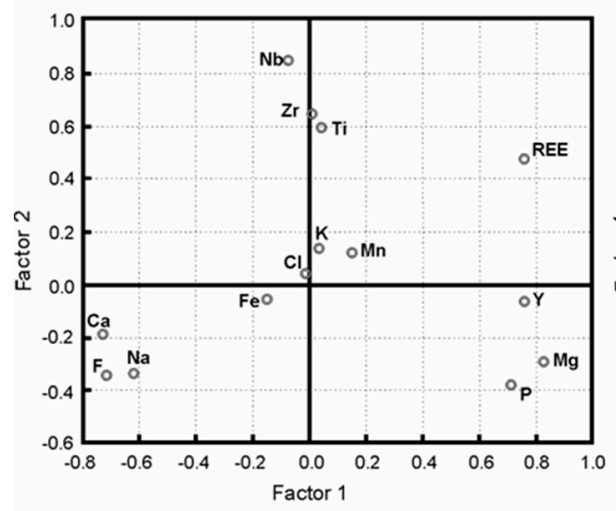

C

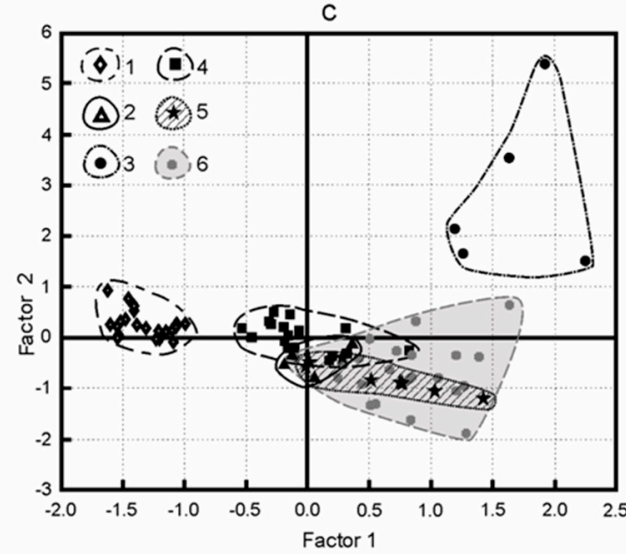

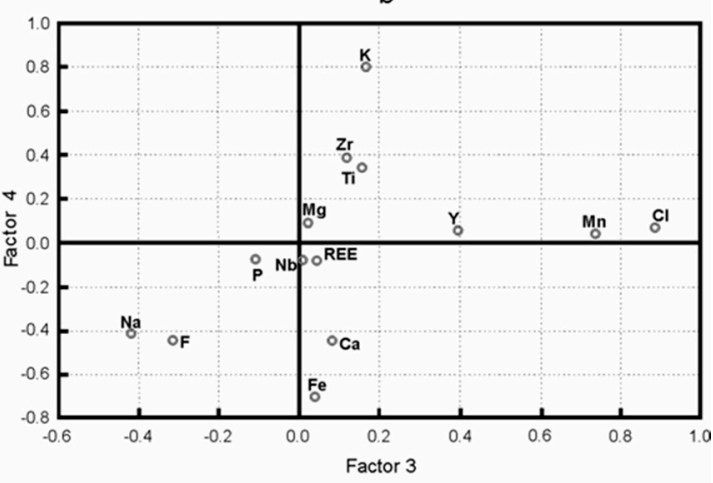

d

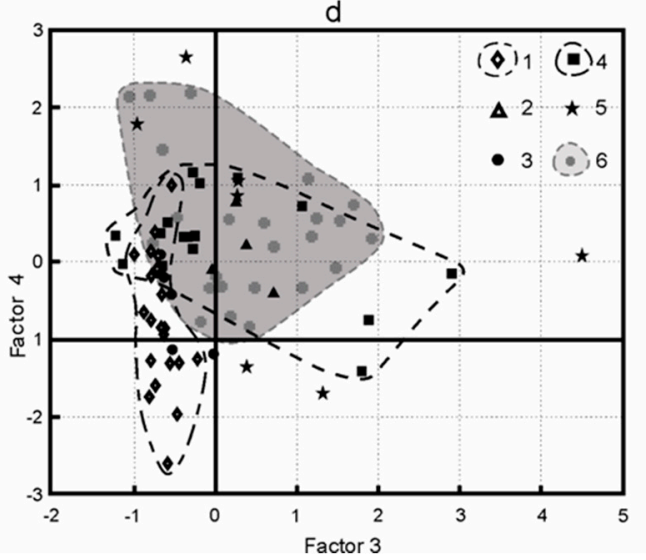

Figure 3. Loadings: Factor 1-Factor 2 (a) and Factor 3-Factor 4 (b). Scores: Factor 1-Factor 2 (c) and Factor 3-Factor 4 (d) with marked material types: 1-hainite-(Y), 2-"eye-like", 3- "homogenous", 4-"layered", 5-“loose", 6-"porous".

\subsection{Factor F1}

Analysis of the factor loading matrix (Table 3, Figure 3a) shows that the first component (factor F1, $27 \%$ of dispersion) binds a group of variables $(\mathrm{Ca}, \mathrm{Na}, \mathrm{F})$ with a close positive correlation. According to scores plot (Figure 3c), F1 clearly differentiates between compositions of hainite-(Y) (points 1) and decationized, cation-deficient samples (points 2-6). In the right part of the plot (Figure 3a, III quadrant), there is the $(\mathrm{Y}, \mathrm{Mg}, \mathrm{P})$ group that has a negative correlation with the first group of variables. It reflects a relationship between the decationization on the one hand and the increased $Y$ content and admixture elements $(\mathrm{Mg}, \mathrm{P})$ present here on the other hand: 
(1) $\mathrm{Ca}^{2+}+\mathrm{Na}^{+}+\mathrm{F}^{-} \leftrightarrow \square+\mathrm{Y}^{3+}+(\mathrm{OH})^{-}$for the main components and $\mathrm{Ca}^{2+}+\mathrm{Na}^{+}+\mathrm{Si}^{4+} \leftrightarrow \square$ $+\mathrm{Mg}^{2+}+\mathrm{P}^{5+}$ or more strictly $(2 a) \mathrm{Ca}^{2+}+2 \mathrm{Na}^{+} \leftrightarrow \square+2 \mathrm{Mg}^{2+}$ or $(2 b) \mathrm{Ca}^{2+}+\mathrm{Na}^{+}+\mathrm{F}^{-} \leftrightarrow \square+\mathrm{Mg}^{2+}+$ $\mathrm{H}_{2} \mathrm{O}$ for the admixture elements $(\mathrm{Mg})$.

This trend is best-observed in samples 5 that have loose structure, but neither visible layering, nor porosity (Figure 3c, points 5). "Layered» (points 4) and "porous" (points 6) are divided less clearly, but still distinctly. Thus, the higher the $\mathrm{Y}, \mathrm{Mg}$, and $\mathrm{P}$ content in a material, the better its destruction is marked.

\subsection{Factor F2}

Variable REE has great loadings both on F1, and on F2 (Figure 3a, II quadrant). It is the opposite of the group $(\mathrm{Ca}, \mathrm{Na}, \mathrm{F})$ and forms diagonal relationship between the objects. The "homogenous" group is associated with this element on scores plot (Figure 3c, points 3). PCA of a dataset on rinkite-(Ce) (a rare-earth analogue of hainite-(Y)) from the Khibiny massif showed a similar correlation [12]. REE are included in the crystal structure according to scheme (3): $\mathrm{Ca}^{2+}+\mathrm{Na}^{+} \leftrightarrow \square+R E E^{3+}$. The authors believe that this scheme reflects the processes, partly at least, when rinkite was decationized, as it was altered. Namely, areas with the maximum REE content being subject to alteration, just like areas with the high $Y$ content. However, they are not destructed, but preserved as "homogenous" relics. The difference in the way the material changes, i.e., with destruction or without it, is attributed to admixture elements $(\mathrm{Mg}, \mathrm{P})$. When the admixture content is high, the mineral is decationized on both schemes (1) and (2a), $(2 b)$ and the material is destructed more intensively. When the admixture content is low, the process follows scheme (3) only, with "homogenous" areas being preserved.

$\mathrm{Nb}$ associated with $\mathrm{Zr}$ and Ti has the greatest loading on Factor F2 (Table 3, Figure 3a). This reflects similar chrystallochemical features of the elements, in the absence of competition in Ti-dominant $\mathrm{M}^{O}$ site $\left(=\mathrm{M}^{\mathrm{O}}(1)\right)$ of the structure. In case of hainite- $(\mathrm{Y})$, the Ti-dominant $\mathrm{M}^{\mathrm{O}}$ site can be incompletely filled by these elements. In case of graph points with the high $Y$ and particularly REE content, the sum of Ti, $\mathrm{Nb}$ and $\mathrm{Zr}$ apfu can reach 1.5 (non-stoichiometric composition).

\subsection{Factor F3}

It is difficult to interpret Factor F3 (Table 3, Figure 3b) with great loadings of Mn and Cl. We may see that $\mathrm{Mn}$ and $\mathrm{Cl}$ are associated with some decationized samples from the groups (points 4-6).

Unlike the $(\mathrm{Ca}, \mathrm{Na}, \mathrm{F})$ group with a load on $\mathrm{F} 1,(\mathrm{Na}, \mathrm{F})$ group has loads both on F3 and F4 (Figure 3b, IV quadrant), which corresponds to the hainite-(Y) composition on scores plot (Figure 3d). It means that we may clearly associate elements to certain positions in the structure: $(\mathrm{Na}, \mathrm{F})$ corresponds with positions in $\mathrm{O}$-layer, and $(\mathrm{Ca}, \mathrm{Na}, \mathrm{F})$ correspond with all cation sites summarily. Hence, group (Zr, Ti) in II quadrant that is the opposite of (Na, F) explains the location of excessive Ti and Zr. They occur in other sites of O-layer, $\mathrm{M}^{\mathrm{O}}(2), \mathrm{M}^{\mathrm{O}}(3)$, according to scheme (4): $4 \mathrm{Na}^{+} \leftrightarrow 3 \square+\mathrm{Ti}^{4+}$. The greater the number of such mixed positions, the more intensively the original material (protophases) alters.

\subsection{Factor F4}

Factor F4 (Table 3, Figure 3b) provides 14\% of dispersion. It follows scheme (5) of isomorphic substitutions: $\mathrm{Ca}^{2+}+\mathrm{Fe}^{3+} \leftrightarrow \mathrm{K}^{+}+\mathrm{Ti}^{4+}\left(\mathrm{Zr}^{4+}\right)$. The scheme works both for hainite-( $\mathrm{Y}$ ) (points 1 along F4), and for "homogenous" REE titanosilicates (points 3) (Figure 3d). It is not confined to leaching.

\section{Discussion}

Statistic analysis of composition of structurally close minerals enables us to detect any correlations between components, both obvious and latent. These correlations reflected the behavior of main and admixture elements and helped us to reconstruct the mineral genesis.

According to the PCA, the main isomorphism with a negative relation of $\mathrm{Na}$ and $\mathrm{Ca}$ (see "Introduction") suggested for the rinkite group minerals is insignificant for minerals of the hainite-(Y)-batievaite-( $(\mathrm{Y})$ series from Sakharjok. Contents of $\mathrm{Y}$ and/or REE increase not with the 
growth of sodium, but, on the contrary, due to its reduction in conjunction with calcium and the appearance (formation) of vacancies according to schemes $\mathrm{Ca}^{2+}+\mathrm{Na}^{+}+\mathrm{F}^{-} \leftrightarrow \square+\mathrm{Y}^{3+}+(\mathrm{OH})^{-}$and $\mathrm{Ca}^{2+}+\mathrm{Na}^{+} \leftrightarrow \square+R E E^{3+}$ (schemes (1) and (3) in Section 3).

Figure 4 shows the temporal relationships between minerals and mineral phases, in addition to the spatial relationships shown in Figures 1 and 2. Statistics data are consistent with geochemical indicators in showing batievaite- $(\mathrm{Y})$ and hainite- $(\mathrm{Y})$ to be minerals of different generations (Figure 4) and batievaite-( $(\mathrm{Y})$ to be prior to hainite- $(\mathrm{Y})$.

Batievaite-(Y) and titanosilicates of intermediate compositions: "eye-like", "layered", "porous" or "loose" titanosilicates are likely to be products of postcrystallization alterations of an early full-cation phase (=protophase). The protophase crystallized in conditions of highly active $\mathrm{CO}_{2}$, while contents $\mathrm{Ca}, \mathrm{Na}$, and $\mathrm{Y}$ were high enough to produce a full-cation phase and a content of $\mathrm{F}$ was low.

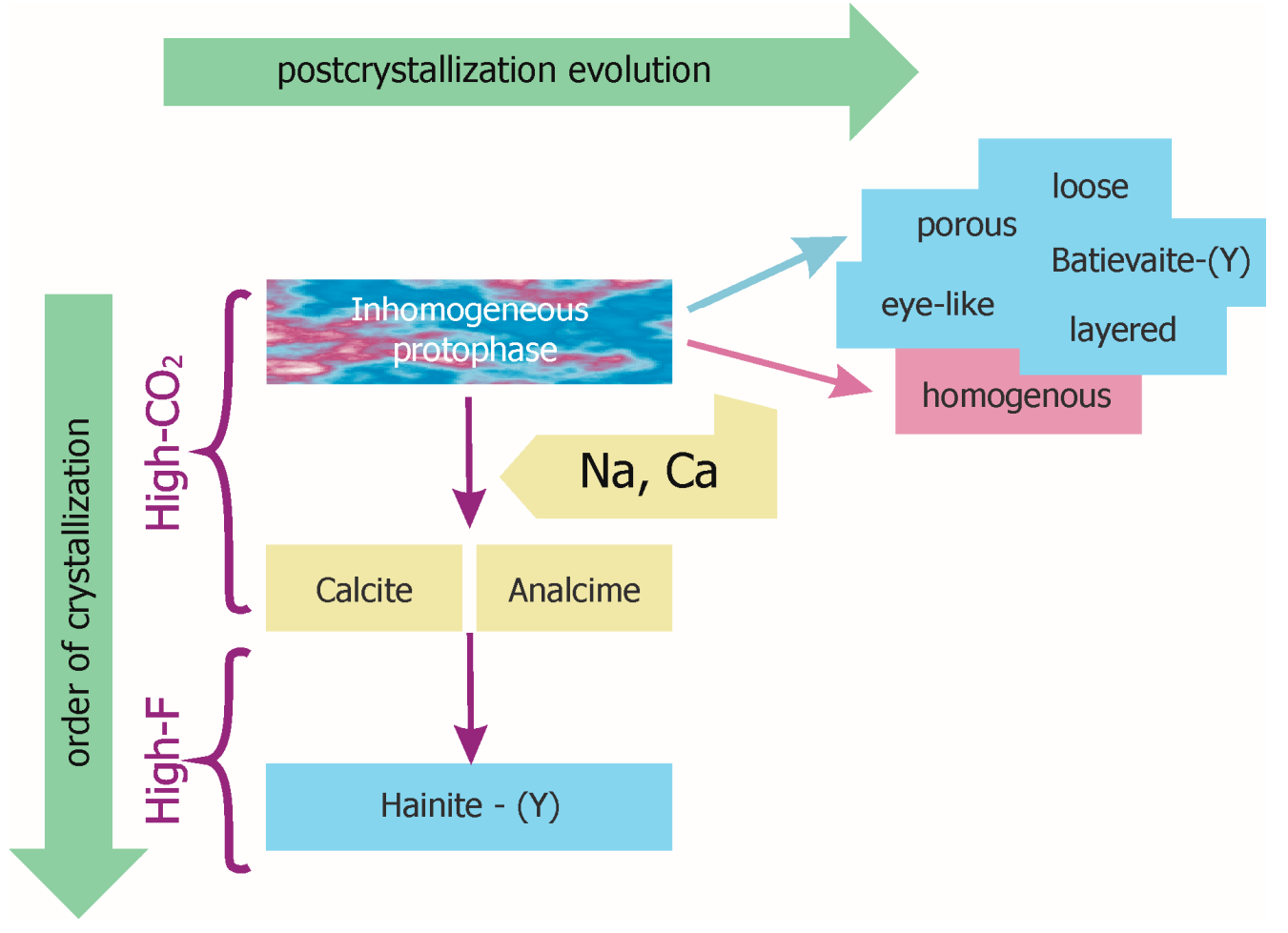

Figure 4. Relationship scheme of the hainite-(Y)-batievaite-(Y) series.

The protophase composition was highly inhomogeneous. It was rich in $R E E, \mathrm{Y}, \mathrm{Ti}$, and $\mathrm{Nb}$ that sometimes increased stoichiometric values (1 apfu). For hainite- $(\mathrm{Y})$ as well for batievaite-( $\mathrm{Y})$ apfu $\mathrm{Ti}+\mathrm{Nb}$ must be 1 in Ti-dominant $\mathrm{M}^{\mathrm{O}}$ site $\left(=\mathrm{M}^{\mathrm{O}}(1)\right)$ of the structure. But, for some studied samples, this value is more than 1 (Table 2, an. 455, 477). There were admixture elements $(\mathrm{Mg}, \mathrm{P}$ ) as well. Schemes (2a) and (2b) (Section 3) indicate that magnesium could be present in the cationic positions of the calcium-sodium in protophase in larger content than in hainite-(Y).

It is possible that the inhomogeneity of the protophase could make it unstable to decationization when fluid regimes change. As for $Y$, we may recall that, e.g., hainite-(Y) from the Sakharjok massif differs from hainite- $(\mathrm{Y})$ from other deposits, not only by its increased $\mathrm{Y}$ content, but also by a deficient analysis sum [13].

Postcrystallization alterations in the protophase with various compositional deviations from stoichiometry are related to the different morphology of studied variations of titanosilicates. There are two distinctive main types of alterations; we call them destructive and non-destructive. The leaching of high yttrium areas should be considered as the first type. The products of such destructive alteration are "eye-like", "layered", "porous", or "loose" textural variations of titanosilicates. Due to protophase inhomogeneity different textural variations showed within same mineral grain. PCA of the chemical 
composition does not allow for distinguishing among these textural variations themselves. Obviously the differences are related to other external, perhaps physical factors. By contrast, REE-enriched areas with the high Ti content, "homogenous", retain integrity (non-destructive alteration type). We believe that collective presence of "homogenous" with "loose", as shown in Figure 2c,d also with "porous" or "layered" titanosilicates indicates their transformation during the same postcrystallization events but from different areas of highly inhomogeneous protophase. Excessive $\mathrm{Ca}$ and $\mathrm{CO}_{2}$, which occurred in the crystallization medium of the protophase, as well as $\mathrm{Ca}$ and $\mathrm{Na}$, which were separated by postcrystallization, deposited as rims of calcite and analcime (Figure 4) and marked the break in the crystallization of titanosilicates (see "Introduction").

When the fluid regime changes (F content increases, $\mathrm{CO}_{2}$ content decreases), and, probably, $\mathrm{Y}$ (and REE) content decreases, the next titanosilicate generation occurs, i.e., hainite-(Y). The mineral overgrowths altered (up to batievaite-(Y)) individuals of the protophase as outer rims. Less often it produces individual crystals.

There is no correlation between the composition and the quantitative ratio of cation-deficient batievaite-like phases to hainite-(Y) in a crystal. The former can be represented either by minor areas ("eye-like"), or by completely altered crystals with a thin hainite-(Y) rim.

Statistic analysis showed that $\mathrm{K}$ and Fe admixtures can be present in any minerals of the series. Their content is not related to the fluid regime change and postcrystallization processes. However, only two data sets indicate its position in the structure: hainite-(Y) data and "homogeneous" phase data (Figure 3d). For other titanosilicates, the presence of potassium does not detect any regularity.

Supplementary Materials: The following are available online at www.mdpi.com/2075-163X/8/10/458/s1, Table S1. Chemical composition (wt \%), formula coefficients based on $\mathrm{Si}+\mathrm{Al}=4$ for titanosilicates of the rinkite group from nepheline-feldspar syenite of the Sakharjok massif, Kola Peninsula.

Author Contributions: Conceptualization, L.M.L.; Methodology, E.A.S.; Formal Analysis, E.A.S.; Investigation, Y.E.S.; Writing-Original Draft Preparation, L.M.L., E.A.S.; Writing-Review \& Editing, L.M.L., E.A.S.; Visualization, L.M.L.

Funding: This research was funded by the Russian Foundation for Basic Research (grant 16-05-00427).

Acknowledgments: The chemical analytical studies were conducted in the Geological Institute, Kola Science Centre, Russian Academy of Sciences. We are grateful to Zozulya D.R. for fruitful discussion and valuable comments.

Conflicts of Interest: The authors declare no conflict of interest.

\section{References}

1. Lyalina, L.M.; Zolotarev, A.A., Jr.; Selivanova, E.A.; Savchenko, Y.E.; Zozulya, D.R.; Krivovichev, S.V.; Mikhailova, Y.A. Structural characterization and composition of Y-rich hainite from Sakharjok nepheline syenite pegmatite (Kola Peninsula, Russia). Miner. Pet. 2015, 109, 443-451. [CrossRef]

2. Lyalina, L.M.; Zolotarev, A.A., Jr.; Selivanova, E.A.; Savchenko, Y.E.; Krivovichev, S.V.; Mikhailova, Y.A.; Kadyrova, G.I.; Zozulya, D.R. Batievaite-(Y), $\mathrm{Y}_{2} \mathrm{Ca}_{2} \mathrm{Ti}_{2}\left[\mathrm{Si}_{2} \mathrm{O}_{7}\right]_{2}(\mathrm{OH})_{2}\left(\mathrm{H}_{2} \mathrm{O}\right)_{4}$, a new mineral from nepheline syenite pegmatite in the Sakharjok massif, Kola Peninsula, Russia. Miner. Pet. 2016, 110, 895-904. [CrossRef]

3. Zolotarev, A.; Krivovichev, S.; Lyalina, L.; Selivanova, E. Crystal structure and chemistry of Na-deficient Y-dominant analogue of hainite/götzenite. Miner. Pet. 2016, 329, 895-904.

4. Sokolova, E. From structure topology to chemical composition: I. Structural hierarchy and stereochemistry in titanium disilicate minerals. Can. Miner. 2006, 44, 1273-1330. [CrossRef]

5. Sokolova, E.; Camara, F.C. The seidozerite supergroup of TS-block minerals: Nomenclature and classification, with change of the following names: Rinkite to rinkite-(Ce), mosandrite to mosandrite-(Ce), hainite to hainite-(Y) and innelite-1T to innelite-1A. Miner. Mag. 2017, 81, 1457-1484. [CrossRef]

6. Pautov, L.A.; Agakhanov, A.A.; Karpenko, V.Y.; Uvarova, Y.A.; Sokolova, E.; Hawthorne, F.C. Rinkite-(Y), IMA 2017-043. CNMNC Newsletter No. 39, October 2017, page 1280. Miner. Mag. 2017, 81, 1279-1286.

7. Cannillo, E.; Mazzi, F.; Rossi, G. Crystal structure of götzenite. Sov. Phys. Crystallogr. 1972, 16, 1026-1030.

8. Christiansen, C.C.; Johnsen, O.; Makovicky, E. Crystal chemistry of the rosenbuschite group. Can. Miner. 2003, 41, 1203-1224. [CrossRef] 
9. Rønsbo, J.G.; Sørensen, H.; Roda-Robles, E.; Fontan, F.; Monchoux, P. Rinkite-nacareniobsite-(Ce) solid solution series and hainite from the Ilímaussaq alkaline complex: Occurrence and compositional variation. Bull. Geol. Soc. Den. 2014, 62, 1-15.

10. Sharygin, V.V.; Stoppa, F.; Kolesov, B.A. Zr-Ti disilicates from the Pian di Celle volcano, Umbria, Italy. Eur. J. Miner. 1996, 8, 1199-1212. [CrossRef]

11. Sokolova, E.; Hawthorne, F.C. From structure topology to chemical composition. XIV. Titaniumsilicates: Refinement of the crystal structure and revision of the chemical formula of mosandrite, $\left(\mathrm{Ca}_{3}\right.$ REE $)\left[\left(\mathrm{H}_{2} \mathrm{O}\right)_{2} \mathrm{Ca}_{0.5} \square 0.5\right] \mathrm{Ti}\left(\mathrm{Si}_{2} \mathrm{O}_{7}\right)_{2}(\mathrm{OH})_{2}\left(\mathrm{H}_{2} \mathrm{O}\right)_{2}$, a Group-I mineral from the Saga mine, Morje, Porsgrunn, Norway. Miner. Mag. 2013, 77, 2753-2771.

12. Konopleva, N.G.; Ivanyuk, G.Y.; Pakhomovsky, Y.A.; Yakovenchuk, V.N.; Mikhailova, Y.A.; Selivanova, E.A. Typochemistry of Rinkite and Products of Its Alteration in the Khibiny Alkaline Pluton, Kola Peninsula. Geol. Ore Depos. 2015, 57, 614-625. [CrossRef]

13. Selivanova, E.A.; Lyalina, L.M. Minerals of rinkite and rosenbuschite groups from Kola Peninsula. Regionalnaya Geologiya, Mineralogiya I Poleznyie Iskopaemyie Kolskogo Poluostrova; Trudy XIII Vserossiyskaya Fersmanovskaya nauchnaya sessiya, Apatity, Russia, 4-5 April 2016; Voytekhovsky, Y.L., Ed.; K \& M: Apatity, Russia, 2016; pp. 97-101. (In Russian)

14. Lyalina, L.M.; Zozulya, D.; Selivanova, E.; Savchenko, Y. Genetic relationship between batievaite-(Y) and hainite-(Y) from Sakharjok nepheline syenite pegmatite, Keivy alkaline province, NW Russia. In Proceedings of the Conference on Accessory Minerals-2017, Vienna, Austria, 13-17 September 2017; pp. 71-72.

15. Khomyakov, A.P.; Yushkin, N.P. The principle of inheritance in crystallogenesis. Dokl. Akad. Nauk SSSR 1981, 256, 1229-1233.

16. Slepnev, Y.S. The minerals of the rinkite group. Izv. Akad. Nauk. USSR Ser. Geol. 1957, 3, 63-75.

17. Lykova, I.S.; Pekov, I.V.; Zubkova, N.V.; Chukanov, N.V.; Yapaskurt, V.O.; Chervonnaya, N.A.; Zolotarev, A.A. Crystal chemistry of cation-exchanged forms of epistolite-group minerals, Part, I. Ag- and Cu-exchanged lomonosovite and Ag-exchanged murmanite. Eur. J. Miner. 2015, 27, 535-549. [CrossRef]

18. Lykova, I.S.; Pekov, I.V.; Zubkova, N.V.; Yapaskurt, V.O.; Chervonnaya, N.A.; Zolotarev, A.A.; Giester, G. Crystal chemistry of cation-exchanged forms of epistolite-group minerals. Part II. Vigrishinite and Zn-exchanged murmanite. Eur. J. Miner. 2015, 27, 669-682. [CrossRef]

19. Batieva, I.D.; Belkov, I.V. Sakharjokskii Peralkaline Massif, Component Rocks and Minerals; Kola Branch of USSR Academy of Sciences: Apatity, Russia, 1984; p. 133. (In Russian)

20. Zozulya, D.R.; Lyalina, L.M.; Eby, N.; Savchenko, Y.E. Ore Geochemistry, Zircon Mineralogy, and Genesis of the Sakharjok Y-Zr Deposit, Kola Peninsula, Russia. Geol. Ore Depos. 2012, 54, 81-98. [CrossRef]

21. Lyalina, L.M.; Savchenko, Y.E.; Selivanova, E.A.; Zozulya, D.R. Behoite and Mimetite from the Saharjok Alkaline Pluton, Kola Peninsula. Geol. Ore Depos. 2010, 52, 641-645. [CrossRef] 